\title{
Engelli Bireylerde Spora Katılımın Önündeki Zorlanmalar Ölçeği Geçerlik ve Güvenirlik Çalışması
}

\author{
Sevim Handan YILMAZ1 ${ }^{(1 D}$, Ekrem Levent ILHAN² (D), Yunus Emre YARAYAN² \\ 1 Gazi Üniversitesi, Eğitim Bilimleri Enstitüsü, ANKARA \\ ${ }^{2}$ Gazi Üniversitesi, Spor Bilimleri Fakültesi, ANKARA
}

Araştırma Makalesi

DOI:10.53434/gbesbd.900837

Öz

Engelli bireylerin toplumsal uyum ve rehabilitasyonunun sağlanabilmesi için yeni düzenlemeler yapılması ve bu sayede engelli bireyler için spora erişilebilirliğin kolaylaştırılması gerekmektedir. Bu nedenle, engelli bireylerin spora katılımlarının önündeki zorlanmalar hakkında bir bilgi kaynağına ihtiyaç vardır. Bu doğrultuda araştırmanın amacı "Engelli Bireylerde Spora Katılımın Önündeki Zorlanmalar Ölçeği"ni geliştirmek, geçerlik ve güvenirlik çalışması yapmaktır. Araştırma karma modelde desenlenmiştir ve bedensel, işitme, görme engelli bireylerden oluşan 298 kişi gönüllü olarak katılmıştır. Araştırma kapsamında elde edilen verilerin analizinde ölçeğin yapı geçerliliği için açımlayıcı faktör analizi, bu analiz neticesinde elde edilen yapının doğrulanması için ise, doğrulayıcı faktör analizi kullanılmıştır. Bu analizler sonucunda; ölçeğin yakınsak geçerliğine kanıt sağlamak amacıyla açıklanan ortalama varyans (AVE) değerlerinin yanı sıra, yapı güvenirliği (CR) değerleri de hesaplanmıştır. Ölçeğin güvenirlik değerlendirmesi için iç tutarlılık katsayıları hesaplanmış, iç tutarlılığın belirlenmesi adına madde toplam test korelasyonları da incelenmiştir. Açımlayıcı faktör analizi sonucunda ölçme aracının Çevresel Zorlanma, Farkındalık ve Duyuşsal Kaçınma olmak üzere 3 boyut ve 14 maddeden oluştuğu tespit edilmiştir. Ölçeğin Cronbach Alpha değerlerinin ise; 0.79 ile 0.91 arasında değiștiği tespit edilmiştir. Araştırma sonucunda; "Engelli Bireylerde Spora Katılımın Önündeki Zorlanmalar Ölçeği”nin geçerli ve güvenilir bir ölçüm aracı olduğu söylenebilir.

Anahtar sözcükler: Engelli birey, Spor, Zorlanma, Geçerlik, Güvenirlik. 


\title{
Validity and Reliability Study of the \\ Difficulties Sports Participation Scale for Persons with Disabilities
}

\begin{abstract}
It is necessary to make new regulations in order to ensure the social adaptation and rehabilitation of the disabled individuals and thus to facilitate the accessibility to sports for the disabled individuals. For this reason, there is a need for a source of information about the difficulties for disabled people to participate in sports. In this direction, the aim of the study is to develop the "Difficulties Sports Participation Scale for Persons with Disabilities" and to study its validity and reliability. The research was designed in a mixed model, and 298 individuals with physical, hearing and visual impairments participated voluntarily. In the analysis of the data obtained within the scope of the research, exploratory factor analysis was used for the construct validity of the scale, and confirmatory factor analysis was used to verify the structure obtained as a result of this analysis. As a result of these analyzes; In addition to the mean variance (AVE) values explained to provide evidence for the convergent validity of the scale, the construct reliability (CR) values were also calculated. Internal consistency coefficients were calculated for the reliability assessment of the scale, and item-total test correlations were also examined in order to determine internal consistency. As a result of the exploratory factor analysis, it was determined that the measurement tool consists of 3 dimensions and 14 items, namely Environmental Strain, Awareness and Affective Avoidance. The cronbach alpha values of the scale are; It was found that it varied between 0.79 and 0.91. As a result, it can be said that "Difficulties Sports Participation Scale for Persons with Disabilities" is a valid and reliable measurement tool.
\end{abstract}

Keywords: Disabled person, Sport, Strain, Validity, Reliability

\section{Giriş}

Tüm bireyler eşit şartlarda dünyaya gelir, kimileri ise birtakım farklılıklara sahiptir. Bireyler arasındaki bu farklılıklar, gelișimin tüm boyutlarını olumlu veya olumsuz etkileyebilmekte, yeterlilikleri ve yetersizlikleri noktasında da belirleyici olabilmektedir (İlhan ve Esentürk, 2014). Ancak eğitim, farklılığı ne olursa olsun tüm bireyler için vazgeçilmez bir haktır. Farklı yeterlilikleri ve ihtiyaçları doğrultusunda eğitim almaları fırsat eșitliği bağlamında anayasal bir zorunluluktur. Fakat bireysel farklılıklarından ve özel gereksinimlerinden kaynaklı olarak bazı bireylerin uyarlama olmaksızın eğitim faaliyetlerinden yararlanabilmeleri mümkün olmamaktadır (Ersoy ve Avcl, 2000). Fiziksel, zihinsel, duygusal ve sosyal gelișim özellikleri bakımından normal gelișim gösteren bireylerden ayrılan, bu bireylerin topluma entegre olabilmeleri açısından özel eğitim ve rehabilitasyon hizmetlerinden yararlanabilmeleri oldukça önemlidir (Altınkurt, 2008). Bireylerin gelişim alanlarındaki yetersizliklerden etkilenme oranlarının artmasıyla birlikte, toplumun beklentilerini karşılamayamamaktadır.

Başka bir deyişle, bireyin herkes gibi olamaması farklılığın en belirgin şekilde ortaya çıktığı noktadır (Güngör, Yılmaz ve İlhan, 2019). Bu değerlendirmeler çerçevesinde bireyler farklı sınıflandırmalar yolu ile tanımlanmaktadır (İlhan ve Esentürk, 2014). Dünya Sağlık Örgütü (WHO, 2001) tarafından yetersizlik; sağlık yönünden "fiziksel yapı ve fonksiyonlardaki" eksiklik ya da anormallik olarak tanımlanırken; bu yetersizlikten kaynaklı olarak yaş, cinsiyet, sosyal ve kültürel etmenlere bağlı olarak bireyden beklenen 
rolün yerine getirememesi engel olarak tanımlanmaktadır. Nitekim engelli bireyler hayatın her alanında pek çok engelle karşılaşabilmektedir. Kendi kendine yeten bir birey olarak yaşayabilmek, topluma uyum sağlayabilmek perspektifinden bakıldığında faydalı olabilecek müdahalelerden biri de şüphesiz ki spordur (Gallahue, 1987). Engelleri sebebiyle, engelli bireylerin ruh halleri ve toplumun kendilerine yönelik tavırlarından kaynaklı olarak oluşan saldırganlık dürtüsü, öfke ve kıskançlık duygularının kontrol altına alınması hususunda, spor oldukça etkili olabilmektedir (İlhan, 2008).

Spor kavramı tüm insanlar için önemli olduğu kadar, engelli bireylerin günlük yaşamlarına hareket katabilmeleri, yeni bir pencere açabilmeleri bakımından farklı bir misyonu da bulunmaktadır (Tekkurşun, İlhan, Esentürk ve Kan, 2018), normal gelişim gösteren bireylere olumlu kazanımlar sağladığı gibi engelli bireylere de pek çok kazanım sağladığı bilinmektedir (İlhan, 2008). Engelli bireylerin topluma ve üretime katılmasının dışında fiziksel açıdan da güçlendirerek günlük yaşamının kolaylaşmasını (Kalyon, 1994) sosyal rolünü kazanmasını sağlamaktadır (İlhan, 2008). Bunların yanı sıra spor engelli bireylerin sosyal rollerini gerçekleștirerek topluma uyum sağlamaları açısından önemli bir fırsat, toplumsal bir deneyim aracıdır (Tekkurşun ve diğerleri, 2018). Özellikle "fiziksel, psikolojik ve sosyal" açından bireylerin gelişimlerini destekleyerek topluma kaynaşmaları noktasında da katkı sağlayabilmektedir (Savucu ve Biçer, 2009). Bu bağlamda da spor; engelli bireylerin tüm gelişim boyutlarını desteklemekte (Tekkurşun ve diğerleri, 2018) toplumda kendilerini ifade edebilecekleri, engellerini unutabilecekleri, özgüven duygusunu arttırabilen sosyal ilişkileri güçlendiren kaynaşmayı sağlayan bir araç olabilmektedir (Kabasakal, 2007). Sporun tüm bu faydaları göz önünde bulundurulduğunda, engelli bireylerin fiziksel ve ruhsal sağlık durumları dikkate alınarak belirlenen, takım sporları ya da bireysel sporlara katılımları desteklenmeli, katılmalarına engel teşkil edebilecek tüm etmenler ortadan kaldırılmalı, engelli bireylerin de engeli olmayan bireyler gibi spor eğitiminden faydalanabilmeleri hususunda firsat eșitliği sağlanmalıdır (Çevik ve Kabasakal, 2013). Ancak engelli bireylerin pek çoğu sportif aktivitelere katılım sağlayamamaktadır (Demir ve İlhan, 2019). Ülkemizde engelli bireylerin spora katılımları üzerinde birçok araştırmanın olduğu görülmektedir (İnal ve diğerleri, 2007).

Özellikle sporun engelli bireylerin beden, ruh ve sosyal sağlıkları üzerindeki olumlu etkileri güncel araştırma konularındandır (Esatbeyoğlu ve Karahan, 2014). Hareket ederek zevk alma, eğlenme ve başarı ihtiyaçlarının karşılanması noktasında sporun engelli bireyler için önemini vurgulayan (Savucu ve Biçer, 2009), bu bireylerin sporda güdülenme yönelimlerini konu alan (Esatbeyoğlu, Balmumcu, Özdamar, Altıntaş ve Aşçı 2009) ve yine bu bireylerin fiziksel uygunlukları üzerindeki pozitif etkilerini inceleyen (Savucu, Sirmen, İnal, Karahan ve Erdemir, 2006) araştırmalar mevcuttur. Gelişmiş toplumlarda engellilere sunulan hizmetler sınır tanımamaktadır. Ülkemizde de son yıllarda engelli vatandaşlarımızın sosyal yaşamları, istihdamları ve eğitimleri gibi konularda geçmiş yıllara göre bazı olumlu gelişmeler yaşanmaktadır. Özellikle Avrupa Birliği uyum yasaları dezavantajlı grupların yaşamlarına doğrudan fayda sağlayacak içerikleriyle ön plana çlkmıştır. 
Çıkarılan kanunlar tam manasıyla hayata geçirildiğinde tüm vatandaşların sosyal hayatında olumlu etkiler oluşturduğunda anlam ifade etmekte ve asıl hedefine ulaşmaktadır. Farklı derecelerde yetersizlikten etkilinmiş bireylerin en bașta yaşam kalitelerinin artması, toplumsal farkındalığın gelişmesi, hareketsiz yaşamlar kültürünün olumsuzluklarından kurtulmaları bakımından son yıllarda farklı çevreler tarafından önemli çabalar ortaya konulmaktadır. Bu uğurda sayıları her geçen gün giderek artan sivil toplum örgütlerinin yanısıra özellikle spor federasyonları da doğrudan bir etkiye sahiptir. Ülkemizde faaliyet gösteren tüm spor federasyonlarının en temel amacı, sporu topluma yaymak, lisanslı sporcu sayısını arttırmak, sporun pek çok faydasından ve dinamik yapısından dolayı sağlıklı, bütünleşik bir toplum oluşturmaktır. Düzenli olarak organize edilen bilimsel toplantıların en gündemde olan konuları arasında engelli bireylerin yaşam koşullarının iyileştirilmesi, zorlanmaların giderilmesi, özel eğitimin yaygınlaştırılması ve bu süreçteki uygulamalar yer almaktadır. Benzer olarak "spor ve engellilerde spor" konulu pek çok çalıştayda ise, ülke ihtiyaçlarına paralel olarak değişen tavsiye kararları alınmaktadır (Nalbant ve Izgar, 2018). Fakat bu bağlamda yapılan çalışmalar incelendiğinde, tüm bunlara rağmen ülkemizde firsat eşitliğinin sağlanamadığı, engelli bireylerin bireysel etmenlerin dışında, büyük çoğunluğunun bireysel olmayan etmenler dolayı spor yapamadığı belirtilmektedir (Demir ve İlhan, 2019). Bu bağlamda bireylerin spor yapmasını zorlaștıran ya da spordan uzaklaștıran faktörlerin olabileceği fikri bu veri toplama aracını geliştirmek için araştırmacılara ilham kaynağı olmuştur. Engelli bireylerde spora katılımın önündeki zorlanmalar; farklı derecelerde yetersizlikten etkilenmiş olan bireylerin spor yapmasını zorlaştıran duygusal kaçınma, farkındalık ve çevresel zorlanma gibi unsurların tümünü ifade etmektedir.

Duygusal kaçınma; bireyin duygusal açıdan karşılaşabileceği olumsuzluklardan kaçınması, bu olumsuz duygulara karşı geri adım atmasıdır. Kaçınma aslında "edimsel tepkinin itici bir uyarıcının verilmesini engellediği" bir koşullama biçimidir (Domjan, 2015). Watson'a (2002) göre, duygular olumlu ve olumsuz duygular şeklinde iki bağımsız faktörden oluşur. Olumsuz duygular "korku, kızgınlık, üzüntü, suçluluk, aşağılanma ve nefret"i kapsarken, olumlu duygular ise "neșe, ilgi ve güven" gibi duyguları kapsamaktadır. $\mathrm{Bu}$ bağlamda bireyin önceden hissettiği olumsuz duygulara bağlı olarak bu olumsuz duyguları bir daha yaşamamak adına kaçınma yolunu izlemesi duygusal kaçınma davranışını oluşturur. Spora katılımın önündeki zorluklar bağlamında duygusal kaçınma, bireysel bir faktör olarak değerlendirilip, bireyin kendi iradesi ile duygusal açıdan kaçınma davranışını karşılık gelmektedir. Farkındalık kavramı, bireyin bütün duyuları ile yaşadığı çevreyi anlamlandırmasının yanı sıra bilinmesi gerekenlerden haberdar olması, kavranması gereken şeylere odaklanması veya hassasiyet göstermesi durumudur (İlhan ve Esentürk, 2014). Spora katılımın önündeki zorluklar bağlamında farkındalık, bireyin spor ve spora katılıma dair tüm konulardaki farkındalığına karşılık gelmektedir. Çevresel zorlanma, zorluk "sıkıntı veya güçlükle yapılma durumu, zor olma, güçlük, zahmet, bir işte engelle karşılaşmak durumu” olarak tanımlanmaktadır (TDK, 2019). Bu bağlamda, çevresel zorlanma ise çevreden kaynaklanan zorluklardan etkilenme olarak tanımlanmaktadır. Bireyin kendisinden kaynaklı nedenlerden zorlanması bireysel zorlanma, çevresel faktörlerden kaynaklı olarak zorlanması ise çevresel zorlanma olarak ifade edilebilir. 
Spora katılımın önündeki zorluklar bağlamında çevresel zorlanma, bireyin çevresel faktörlerden kaynaklı olarak spora katılımda zorlanmasına karşılık gelmektedir. Çevresel faktörler ise, spor ortamına dair fiziki şartlar, ulaşım, tesis ve donanımı ifade etmektedir. $\mathrm{Bu}$ doğrultuda literatürde yer alan araştırmalar incelendiğinde görülmektedir ki, özel eğitim ve rehabilitasyon merkezlerinde engelli bireylerin ihtiyaçlarına göre tasarlanmış sportif aktiviteleri yapabilecekleri alanların, aktivite sırasında kullanabilecekleri materyallerin ve bu alanda faydalanabilecekleri uzman eğitmenlerin olmayışı engelli bireylerde spora katılım önündeki zorlanmaların başında gelmektedir (İlhan, Orhan ve Yarımkaya, 2018).

Chinn, White, Howel, Harland ve Drinkwater (2006) engelli bireylerde fiziksel aktiviteye katılım önündeki zorlanmaları inceledikleri araştırma sonucunda, engelli bireylerin "evi yalnız bırakmama, fiziksel aktiviteden hoşlanmama, bireysel sağlık sorunu, beraber fiziksel aktivite yapacak birisini bulamama" gibi nedenlerden kaynaklı olarak fiziksel aktivite yapamadıklarını tespit etmiştir. Tenenbaum ve Eklund (2007) ise, engelli bireylerde spor katılım önündeki en büyük engelin zaman ve motivasyon eksikliği olduğunu ileri sürmektedir. Kirchner, Gerber ve Smith (2008), farklı engel gruplarına sahip bireylerin fiziksel aktiviteye katılımlarını etkileyen zorlanmaları belirlemek amacı ile yapmış olduğu araştırma sonucunda, yaya kaldırımlarının, inşaat faaliyetlerinin, pervaz ve kanalizasyonların bireyler için engel teşkil ettiğini tespit etmiştir.

Esatbeyoğlu ve Karahan (2014), engelli bireylerde fiziksel aktiviteye katılımının önündeki zorlanmaları belirlemek amacı ile yapmış oldukları araştırma sonucunda, katılımın önünde sosyal, fiziksel, bireysel, ekonomik, psikolojik ve engel durumuna bağlı zorlanmalar olabileceğini tespit etmiştir. Zorlanmaların belirlenmesi ve giderilmesinin engelli bireylerin özellikle toplumla entegre olabilmesi açısından oldukça önemli olduğu (Jaarsma, Dijkstra, Geertzen ve Dekker, 2014) dikkate alındığında, şartların her geçen gün iyileşmesi gerektiği söylenebilir. Bu amaçla öncelikle rehabilitasyon merkezlerinde ve yerel belediyelerde, engelli bireylerin rahatlıkla ulaşabileceği ve konforlu şekilde kullanabileceği çok amaçlı spor alanlarının oluşturulması (Çevik ve Kabasakal, 2013), spor ile ilgili her türlü bilgi edinebilme amacıyla, özel eğitim ve rehabilitasyon merkezlerinde beden eğitimi öğretmeni bulundurma zorunluluğu ile ilgili yasal düzenlemelerin yapılması (Nalbant ve Izgar, 2018), ailelerin sporu tanımaları amacı ile bilgilendirme faaliyetlerinin gerçekleştirilmesi (İlhan, Orhan ve Yarımkaya, 2018), engelli bireylerin toplumsal entegrasyon ve rehabilitasyonunun sağlanabilmesi için sporun ne kadar önemli olduğunun eğitim kurumlarında anlatılması (Konar ve Yıldıran, 2012), ülkemizin mevcut durumu gözden geçirilerek yeni düzenlemeler yapılması ve bu sayede engelli bireyler için spora erişilebilirliğin kolaylaştırılması gerekmektedir.

$\mathrm{Bu}$ nedenle engelli bireylerin spora katılımlarının önündeki zorlanmalar hakkında bilgi kaynağına ihtiyaç vardır ve zorlanmaların tüm boyutlarıyla ölçülebilmesine amacı ile bir veri toplama aracının geliștirilmesi büyük önem taşımaktadır. Bu bağlamda çalışmanın amacı, engelli bireylerin spora katılımlarında engel oluşturabilecek faktörleri ölçebilecek geçerli ve güvenilir bir veri toplama aracı geliştirmektir. 


\section{Yöntem}

\section{Araştırmanın Modeli}

$\mathrm{Bu}$ araştırma, nicel ve nitel verilerin aynı zamanda ya da ardışık (sıralı) olarak toplandığı ve analiz edildiği, çalışmanın bir ya da birden çok aşamasında verilerin bütünleștirildiği karma yöntem modeli (Creswell, 2013) ile tasarlanmıștır.

\section{Araştırma Grubu}

Araştırmaya bedensel, işitme ve görme engelli bireylerden 139'u kadın ( $\mathrm{X}_{\mathrm{yas}}=$ $69 \pm 9,30), 159$ 'u erkek $\left(X_{\text {yaș }}=28,73 \pm 11,27\right.$ ) olmak üzere toplam 298 kişi gönüllü olarak katılım sağlamıștır. Katılımcılar kolay ulaşılabilirlik ve ekonomiklik göz önünde bulundurularak uygun örnekleme yöntemiyle seçilmiştir (Gravetter ve Forzano, 2012).

$\mathrm{Bu}$ araştırma, Bartın Üniversitesi Sosyal ve Beşeri Bilimleri Etik Kurulu'nun 30.07.2020 tarih ve 2020-SBB-0157 sayılı kararı ile etik açıdan uygun bulunmuştur.

Tablo 1. Araştırma grubuna ilişkin tanımlayıcı istatistiki bilgiler

\begin{tabular}{lccc}
\hline & Değişkenler & $\mathbf{n}$ & $\mathbf{\%}$ \\
\hline \multirow{3}{*}{ Cinsiyet } & Kadın & 139 & 46.6 \\
& Erkek & 159 & 53.4 \\
& Toplam & 298 & 100.0 \\
\hline \multirow{3}{*}{ Engel Türü } & Bedensel Engelli & 106 & 35.6 \\
& Görme Engelli & 90 & 30.2 \\
& İşitme Engelli & 102 & 34.2 \\
& Toplam & 298 & 100.0 \\
\hline \multirow{3}{*}{ Engel Durumu } & Doğuştan & 188 & 63.1 \\
& Sonradan Oluşan & 110 & 36.9 \\
& Toplam & 298 & 100.0 \\
\hline \multirow{3}{*}{ Spor Deneyimi } & Var & 151 & 50.7 \\
& Yok & 147 & 49.3 \\
& Toplam & 298 & 100.0 \\
\hline
\end{tabular}

Tablo 1'de araştırma kapsamına alınan bireylerin demografik bilgilerine yönelik frekans ve yüzdelik dağımları görülmektedir. Bu doğrultuda bireylerin \%46.6'sının (n:139) kadın, \%53.4'ünün (n:159) erkek olduğu tespit edilmiştir. Engel türü incelendiğinde, \%35,6'sının (n:106) bedensel engelli, \%30.2'sinin (n:90) görme engelli ve \%34.2'sinin (n:102) ișitme engelli olduğu görülmektedir. Engel durumuna bakıldığında, \%63.1'inin (n:188) doğuștan engel grubunda, \%36.9'unun (n:110) sonradan oluşan engel grubunda olduğu belirlenmiștir. Son olarak spor deneyimi değișkeni incelendiğinde, \%50.7'sinin (n: 151) spor deneyiminin olduğu, \%63.1'inin (n:147) spor deneyiminin olmadığı tespit edilmiştir. 
İşlem

Elde edilen veriler değerlendirildikten sonra işlem bölümüne geçilmiş ve ölçeğin geliştirilme sürecinde izlenen bölümler aşamalı olarak sunulmuştur.

\section{Ölçeğin Geliștirilme Süreci}

\section{Yarı Yapılandırılmış Görüşme ve Literatür Taraması}

Ölçeğin geliştirme sürecinde ilk olarak, bedensel, işitme ve görme engelli 11 sporcu ile antrenörlerinin de eşlik etmeleriyle, yarı yapılandırılmış görüşme formu ile yüz yüze görüşmeler gerçekleştirilmiştir. $\mathrm{Bu}$ görüşmeler araştırmanın nitel aşamasını oluşturmaktadır. Bu kapsamda elde edilen bilgiler araştırmacılar tarafından madde haline getirilmiştir. Bu aşamadan sonra ilgili alanyazın incelenmiş ve engelli bireylerin spora katılımını engelleyebilecek faktörler üzerine farklı maddeler yazılmıştır. Bu doğrultuda iki uygulama sonrası yazılmış olan maddeler üzerine tartıșılmış ve toplam 32 ifadeden oluşan madde havuzu oluşturulmuştur. Elde edilen bu form beşli Likert derecelendirmesine uygun olacak şekilde "kesinlikle katılmıyorum" ve "kesinlikle katılıyorum" arasında değişen seçenekler ile değerlendirilmiştir.

\section{Uzman Görüșünün Alınması (İçerik-Kapsam Geçerliliği)}

$\mathrm{Bu}$ aşamadan sonra hazırlanan 32 soruluk deneme formu uzman görüşleri alınmak üzere faal olarak engelli bireylerle çalışan Özel Beden Eğitimi ve Spor alanından üç uzman, Türk Dili ve Edebiyatı alanından iki uzman, Eğitimde Ölçme ve Değerlendirme alanından ise iki uzman görüşüne sunulmuştur. Uzmanlardan gelen dönütler doğrultusunda aynı durumları ölçtügü düşünülen 5 madde taslak formdan çıkarılarak ölçeğin 27 maddeden oluşan uygulama formu oluşturulmuştur.

\section{Pilot Çalışma Uygulaması}

Ölçeğin geçerlik ve güvenirlik çalışmalarına geçilmeden önce uygulama formu için oluşturulan 27 ifadenin anlaşılabilirliğini kontrol etmek amacıyla 15 engelli bireyin katılımı ile pilot uygulama yapılmıştır. Gerçekleştirilen uygulama sırasında bireylerin anlamakta zorlandıkları bir ifade daha ölçekten çıkarılarak elde edilen 26 maddelik nihai formun ölçek geliştirme aşamasında kullanılmasına karar verilmiştir.

\section{Veri Toplama Araçları}

\section{Engelli Bireylerde Spora Katılımın Önündeki Zorlanmalar Ölçeği}

Geçerlik ve güvenirlik çalışması yapılan, "Engelli Bireylerde Spora Katılımın Önündeki Zorlanmalar Ölçeği” 14 madde ve 3 alt boyuttan (Çevresel Zorlanma, Farkındalık ve Duyuşsal Kaçınma) oluşmaktadır. Engelli bireylerin spor yapmamasına neden olan zorlukları ortaya koymak amacıyla geliştirilen ölçek 5'li likert tipi şeklinde değerlendirilmektedir (Ek-1). Ölçekte ters kodlanan madde bulunmamaktadır ve ölçek toplam puan vermektedir. Geliştirilen ölçek, katılımcıların aldığı puanlar arttıkça bireylerin karşılaştıkları zorlukların arttığı, puanlar düştükçe bu zorlukların azaldığı yönünde değerlendirilmektedir. 


\section{Ölçeğin Uygulama Aşamasl}

Veriler yüz yüze ve çevrimiçi form aracıllğıyla toplanmıştır. Yüz yüze görüşmelerde formlar katılımcılara dağıtılmadan önce çalışmanın bilimsel boyutundan bahsedilmiştir. Bu doğrultuda verilen cevaplarda samimi ve tutarlı olunmasının en doğru sonuca ulaşmayı sağlayacağı belirtilmiştir. Verilerin toplanmasında herhangi bir süre kısıtlaması yapılmamıştır. Bununla birlikte araştırma kapsamında ulaşılacak sonuçlar hakkında bilgi verilebileceği belirtlilerek, talep doğrultusunda katılımcılardan e-posta adresi alınmıștır.

\section{Verilerin Çözümlenmesi ve Yorumlanması}

Verilerin analizi için Microsoft Excel, SPSS 22 ve AMOS 22 bilgisayar programları kullanılmıştır. Araştırmada ilk olarak boş verilerin değerlendirmesi yapılmıştır. Bu aşamadan sonra Mahalanobis uzaklığı göz önünde bulundurularak uç değer analizleri gerçekleştirilmiştir. $\mathrm{Bu}$ işlemler sonucunda, hatalı ve eksik dolduran 12 kişinin, Mahalanobis uzaklığı göz önünde alındığında ise 11 kişinin vermiş olduğu yanıtlar araştırma kapsamı dışında bırakılarak kalan 298 kişinin verileri üzerinden analizler yapılmıştır.

Literatür taraması üzerine (Carpita ve Manisera, 2011; Downey ve King, 1998) bir değer atamak veya analiz dışı bırakmak gibi tekniklerin olduğunu belirtmektedir. Bu kapsamda araştırma grubunun sayısı ve bu 23 verideki ölçek maddelerine verilen cevapların eksikliği göz önüne alınarak bu verilerin çıkarılmasına karar verilmiştir.

$\mathrm{Bu}$ aşamadan sonra ilk olarak gözlenen değişkenlerin normallik varsayımları için Tabachnick ve Fidell (2013) önerdiği $-1,5 \pm 1,5$ çarpıklık basıklık değerleri dikkate alınmış ve dağllımın normal olduğu tespit edilmiștir.

$\mathrm{Bu}$ doğrultuda ölçeğin yapı geçerliği için faktör yapısını belirlemek amacıyla Açımlayıcı Faktör Analizi (Exploratory Factor Analysis) kullanılmıştır. Bu analiz sonucunda elde edilen yapının doğrulanması gözlenen ve örtük değişkenlerin uyum iyiliği indeks değerleri için ise Doğrulayıcı Faktör Analizi (Confirmatory Factor Analysis) kullanılmıştır.

Ayrıca ölçeğin yapı geçerliğine kanıt sağlamak amacıyla alt boyutlar arası korelasyon değerleri de hesaplanmıştır. Araştırma kapsamında geliştirilen ölçeğin yakınsak geçerlik için ise açıklanan ortalama varyans (AVE) değerlerinin yanı sıra, yapı güvenirliği (CR) değerleri hesaplanmıştır. Ölçeğin güvenirliğini belirlemek amacıyla, Cronbach Alpha güvenirlik katsayısı hesaplanmıștır. Bununla birlikte her bir maddenin geçerliğine ve ayırt edicilik özelliğine kanıt sağlamak amacıyla madde toplam test korelasyon değerleri de incelenmiştir.

\section{Bulgular}

Araştırmanın bu bölümünde ölçeğe ilişkin katılımcılardan elde edilen veriler üzerinde yapılan analiz sonuçlarına iliş̧in bulgulara yer verilmiştir. Bu doğrultuda Tablo 2'de ölçeği oluşturan 14 gözlenen değişkene ait ortalama, standart sapma, basıklık ve çarpıklık değerlerine ilişkin tanımlayıcı istatistiki bulgular sunulmuştur. 
Tablo 2. Ölçeğe ilişkin tanımlayıcı istatistiki bilgiler

\begin{tabular}{clrccc}
\hline & Maddeler (Gözlenen Değişkenler) & Ortalama & Ss & Carpıklık & Basıklık \\
\hline 1 & Spor için ayıracak zamanım yok & 2.29 & 1.24 & .617 & -.586 \\
\hline 2 & Sporun engel düzeyimi arttırabileceğine inanıyorum & 2.12 & 1.36 & .872 & -.526 \\
\hline 3 & Spor yapmaya ilgi duymuyorum & 2.36 & 1.37 & .539 & -.921 \\
\hline 4 & Spora yönelik bir yeteneğim olmadı̆̆ına inanıyorum & 1.99 & 1.21 & .991 & -.038 \\
\hline 5 & $\begin{array}{l}\text { Bir spora başlasam devam edemeyeceğimi } \\
\text { düșünüyorum }\end{array}$ & 2.77 & 1.37 & .188 & -1.100 \\
\hline 6 & $\begin{array}{l}\text { Antrenörlerin engelliler konusunda gerekli } \\
\text { formasyona sahip olmadığını düşünüyorum }\end{array}$ & 2.81 & 1.31 & .063 & -1.097 \\
\hline 7 & $\begin{array}{l}\text { Spor ortamlarında sosyal olarak dışlanacağımı } \\
\text { düșünüyorum }\end{array}$ & 2.74 & 1.33 & .256 & -.978 \\
\hline 8 & $\begin{array}{l}\text { Spor yapmak için bana eşlik edecek / destek olacak } \\
\text { kimse yok }\end{array}$ & 3.03 & 1.31 & -.050 & -1.007 \\
\hline 9 & Spora katılım için ne yapacağımı bilmiyorum & 3.16 & 1.33 & -.095 & -1.051 \\
\hline 10 & $\begin{array}{l}\text { Spor tesisleri iç donanımlarının (erişim, duş, wc vb.) } \\
\text { bana göre olmadığını düşünüyorum }\end{array}$ & 3.16 & 1.30 & -.080 & -.944 \\
\hline 11 & Spor ortamları hijyen açısından uygun değildir & 2.95 & 1.20 & .074 & -.694 \\
\hline 12 & $\begin{array}{l}\text { Spor ortamları çevresel düzenlemeler ya da } \\
\text { ergonomi yönünden güvenli değildir }\end{array}$ & 2.90 & 1.23 & .160 & -.786 \\
\hline 13 & $\begin{array}{l}\text { Spor tesislerine ulaşımda zorluk yaşayacağımı } \\
\text { düșünüyorum }\end{array}$ & 3.02 & 1.35 & -.018 & -1.103 \\
\hline 14 & Gelir düzeyim düşük olduğu için spor yapamıyorum & 2.96 & 1.41 & .029 & -1.241 \\
\hline & & & &
\end{tabular}

Tablo 2'de ölçeği oluşturan maddelerin çarpıklık ve basıklık değerleri görülmektedir. Gözlenen değişkenlere ilişkin çarpıklık değerlerinin -.018 ile.991 arasında olduğu, basıklık değerlerinin ise -.038 ile -1.241 arasında olduğu belirlenmiştir.

\section{Ölçeğin Yapı Geçerliliği}

\section{Açımlayıcı Faktör Analizi}

AFA analizini gerçekleştirmek için verilerin uygunluğu Kaiser-Mayer-Olkin (KMO) katsayısı ve Bartlett küresellik testiyle belirlenmiştir. Bu sonuçlar Tablo 3'te verilmiştir.

Tablo 3. Ölçek KMO ve barlett testi sonu

\begin{tabular}{lcl}
\hline Örneklem Ölçüm Uygunluğu & & Değerler \\
\hline KMO & & .892 \\
\hline \multirow{2}{*}{ Bartlett Küresellik Testi } & $\mathrm{x}^{2}$ & 2355.529 \\
& $\mathrm{Sd}$ & 91 \\
\hline
\end{tabular}

* $\mathrm{p}<0.01$

Tablo 3'te yapılan analiz sonucunda Kaiser-Meyer-Olkin değerinin .89 olduğu, Bartlett küresellik testinin sonucunun da anlamlı $\left(x^{2}=2355.529\right.$, $\left.s d=91, p=.000\right)$ olduğu tespit edilmiştir. Tabachnick ve Fidell (2013) göre elde edilen bu değerler değişkenler için faktör analizinin uygun olduğunu göstermektedir. 
Bu kapsamda uygulanan temel bileșenler analizi sonucunda elde edilen alt boyutların faktör yükleri ve açıkladığı varyans Tablo 4'te verilmiştir.

Tablo 4. Ölçeğe ilişkin faktör analizi sonuçları

\begin{tabular}{|c|c|c|c|c|c|}
\hline Alt Boyutlar & & Maddeler & $\begin{array}{c}\text { Faktör } \\
\text { Yükleri }\end{array}$ & $\begin{array}{l}\text { Açıkladığı } \\
\text { \% Varyans }\end{array}$ & $\begin{array}{l}\text { Toplam } \\
\text { Varyans } \\
\end{array}$ \\
\hline \multirow{5}{*}{$\begin{array}{l}\text { Çevresel } \\
\text { Zorlanma }\end{array}$} & 15 & $\begin{array}{l}\text { Spor tesisleri iç donanımlarının (erişim, duş, wc } \\
\text { vb.) bana göre olmadığını düşünüyorum }\end{array}$ & .871 & \multirow{5}{*}{25.123} & \multirow{14}{*}{66.785} \\
\hline & 16 & Spor ortamları hijyen açısından uygun değildir & .825 & & \\
\hline & 17 & $\begin{array}{l}\text { Spor ortamları çevresel düzenlemeler ya da } \\
\text { ergonomi yönünden güvenli değildir. }\end{array}$ & .783 & & \\
\hline & 14 & $\begin{array}{l}\text { Spor tesislerine ulaşımda zorluk yaşayacağımı } \\
\text { düşünüyorum }\end{array}$ & .735 & & \\
\hline & 18 & Gelir düzeyim düşük olduğu için spor yapamıyorum & .618 & & \\
\hline \multirow{5}{*}{ Farkındalık } & 21 & Spora katılım için ne yapacağımı bilmiyorum & .789 & \multirow{5}{*}{21.762} & \\
\hline & 12 & $\begin{array}{l}\text { Spor ortamlarında sosyal olarak dışlanacağımı } \\
\text { düşünüyorum }\end{array}$ & .710 & & \\
\hline & 9 & $\begin{array}{l}\text { Bir spora başlasam devam edemeyeceğimi } \\
\text { düşünüyorum }\end{array}$ & .706 & & \\
\hline & 11 & $\begin{array}{l}\text { Antrenörlerin engelliler konusunda gerekli } \\
\text { formasyona sahip olmadığını düşünüyorum }\end{array}$ & .652 & & \\
\hline & 13 & $\begin{array}{l}\text { Spor yapmak için bana eşlik edecek / destek olacak } \\
\text { kimse yok }\end{array}$ & .623 & & \\
\hline \multirow{4}{*}{$\begin{array}{l}\text { Duyuşsal } \\
\text { Kaçınma }\end{array}$} & 8 & $\begin{array}{l}\text { Spora yönelik bir yeteneğim olmadığına } \\
\text { inanıyorum }\end{array}$ & .845 & \multirow{4}{*}{19.900} & \\
\hline & 4 & Spor için ayıracak zamanım yok. & .742 & & \\
\hline & 5 & $\begin{array}{l}\text { Sporun engel düzeyimi arttırabileceğine } \\
\text { inanıyorum. }\end{array}$ & .700 & & \\
\hline & 6 & Spor yapmaya ilgi duymuyorum. & .656 & & \\
\hline
\end{tabular}

Tablo 4'te yapılan faktör analizi sonucunda oluşan üç faktörlü bir yapıdan oluştuğu tespit edilmiştir. Elde edilen bu faktörler varyansın \%66.785'ini açıkladığı görülmektedir. Çevresel Zorlanma alt boyutunun açıklanan varyansa katkısı \%25.123, Farkındalık alt boyutunun varyansa katkısı \%21.762, Duyuşsal Kaçınma alt boyutunun varyansa katkısı ise, \%19.900 olduğu tespit edilmiștir. Bununla birlikte alt boyutlara ilișkin faktör yükleri incelendiğinde, Çevresel Zorlanma, 0.70 - 0.87, Farkındalık, 0.62 - 0.79, Duyuşsal Kaçınma, alt boyutunun faktör yüklerinin ise 0.66 - 0.85 arasında değiștiği tespit edilmiştir.

\section{Doğrulayıcı Faktör Analizi}

AFA analizi neticesinde üç boyuttan oluşan yapıyı doğrulamak amacıyla AMOS programı kullanılarak doğrulayıcı faktör analizi (DFA) uygulanmıştır. DFA analizi için kriter alınan çoklu uyum indeks değerleri Tablo 5 'te sunulmuștur.

Tablo 5. Ölçeğe ilişkin modifikasyon öncesi doğrulayıcı faktör analizine ilişkin uyum indeks değerleri

\begin{tabular}{ccccccccc}
\hline $\mathbf{x}^{\mathbf{2}}$ & $\mathbf{d f}$ & $\mathbf{p}$ & $\mathbf{x}^{2 / \mathbf{d f}}$ & $\mathbf{R M S E A}$ & $\mathbf{S R M R}$ & CFI & GFI & IFI \\
\hline 303.818 & 74 & 0.00 & 4.106 & 0.102 & 0.059 & 0.90 & 0.88 & 0.90 \\
\hline
\end{tabular}


Tablo 5'te üç faktörlü yapıya dönük olarak gerçekleştirilen doğrulayıcı faktör analizinde model üzerinde önerilen modifikasyon yapılmadan önce elde edilen uyum iyiliği indeksleri değerleri görülmektedir. Modifikasyon öncesi ölçüm modeline ilişkin 14 gözlenen değişkenin standardize edilmiş faktör yük değerlerinin, .60 ile .86 arasında değiştiği görülmektedir.

Bu kapsamda modelin uyum iyiliği indeks değerleri incelendiğinde, RMSEA değerinin literatür kapsamında belirtilen değerler altında olması sebebiyle önerilen modifikasyon yapılmış ve uyum indeks değerleri Tablo 5 'te verilmiştir.

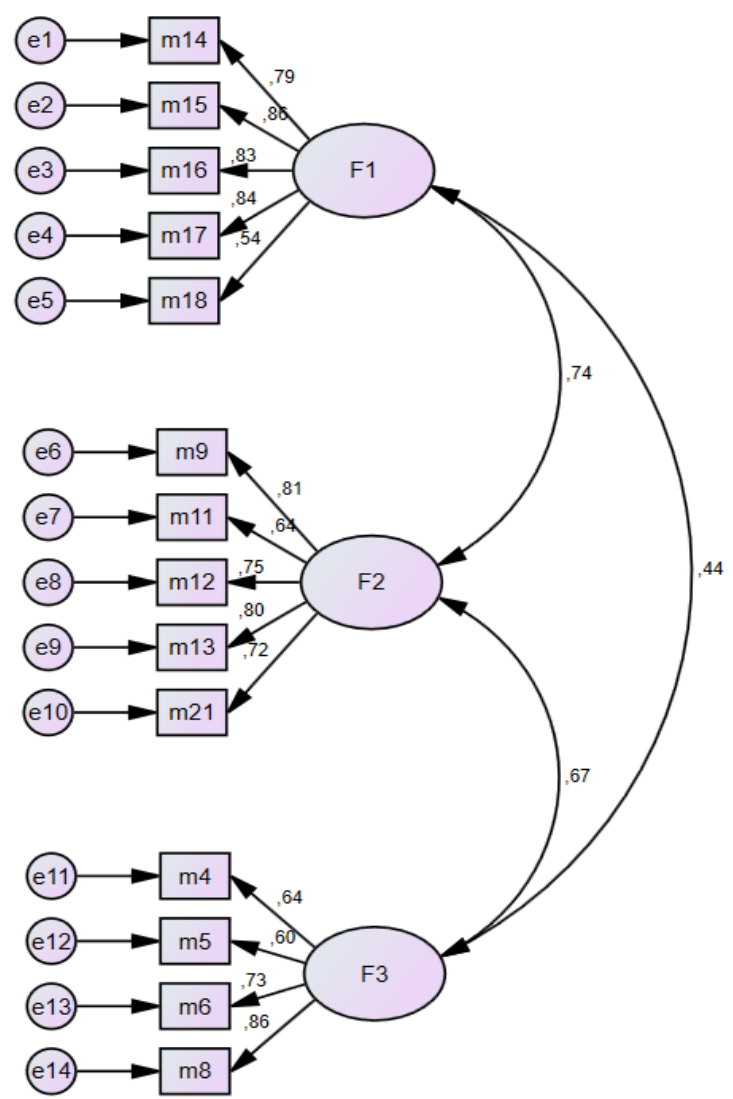

F1: Çevresel Zorlanma, F2: Farkındalık, F3: Duyuşsal Kaçınma

Şekil 1. Modifikasyon öncesi doğrulayıcı faktör analizine ilişkin path diyagramı

Tablo 6. Ölçeğe ilişkin modifikasyon sonrası doğrulayıcı faktör analizine ilişkin uyum indeks değerleri

\begin{tabular}{ccccccccc}
\hline $\mathbf{x}^{\mathbf{2}}$ & $\mathbf{d f}$ & $\mathbf{p}$ & $\mathbf{x}^{2 / \mathbf{d f}}$ & $\mathbf{R M S E A}$ & $\mathbf{S R M R}$ & $\mathbf{C F I}$ & GFI & IFI \\
\hline 278.503 & 73 & 0.00 & 3.815 & 0.097 & 0.057 & 0.91 & 0.90 & 0.91 \\
\hline
\end{tabular}


Tablo 6'da aynı alt boyutta bulunan m14-m18 arasında gerçekleştirilen modifikasyon önerisi sonrası uyum indeks değerleri incelendiğinde, $\mathrm{x}^{2} / \mathrm{df}$ değerinin 3.815 olduğu tespit edilmiștir. Kline (2015), $\mathrm{x}^{2}$ /df değerinin 3'ün altında olmasının modelin mükemmel uyumu ifade ettiğini, 5'in altında olmasının ise kabul edilebilir uyum göstergesi olduğunu belirtmektedir. RMSEA değeri incelendiğinde, 0.097 olarak tespit edilmiştir. Kline (2015) ve Steiger (2000), 0.08 ve 0.10 arasındaki değer aralıklarının modelin orta düzeyde bir uyum gösterdiğini ifade etmektedir. SRMR değerine bakıldığında, 0.057 olarak tespit edilmiştir. Kline (2015) bu değerin 0,10'un altında olmasının modelin iyi uyum göstergesi olduğunu ifade etmektedir. CFI değeri 0.91, GFI değeri 0.90, IFI değeri ise 0.91 olarak tespit edilmiștir. Literatür kapsamında 0.90 ve üstü bir değerin iyi uyum düzeyi olduğu görülmüştür (Byrne, 2010; Kline, 2015; Thompson, 2004).

Ayrıca 14 gözlenen değişkeninin standardize edilmiş faktör yük değerlerinin, .60 ile .86 arasında değiştiği görülmektedir. Araştırma kapsamında elde edilen sonuçlar doğrultusunda 14 maddelik "Engelli Bireylerde Spora Katılımın Önündeki Zorlanmalar Ölçeği”nin 3 faktörlü yapısının doğrulandığı ve DFA analizi sonucu elde edilen modelin kabul edilebilir bir uyum gösterdiği ifade edilebilir.

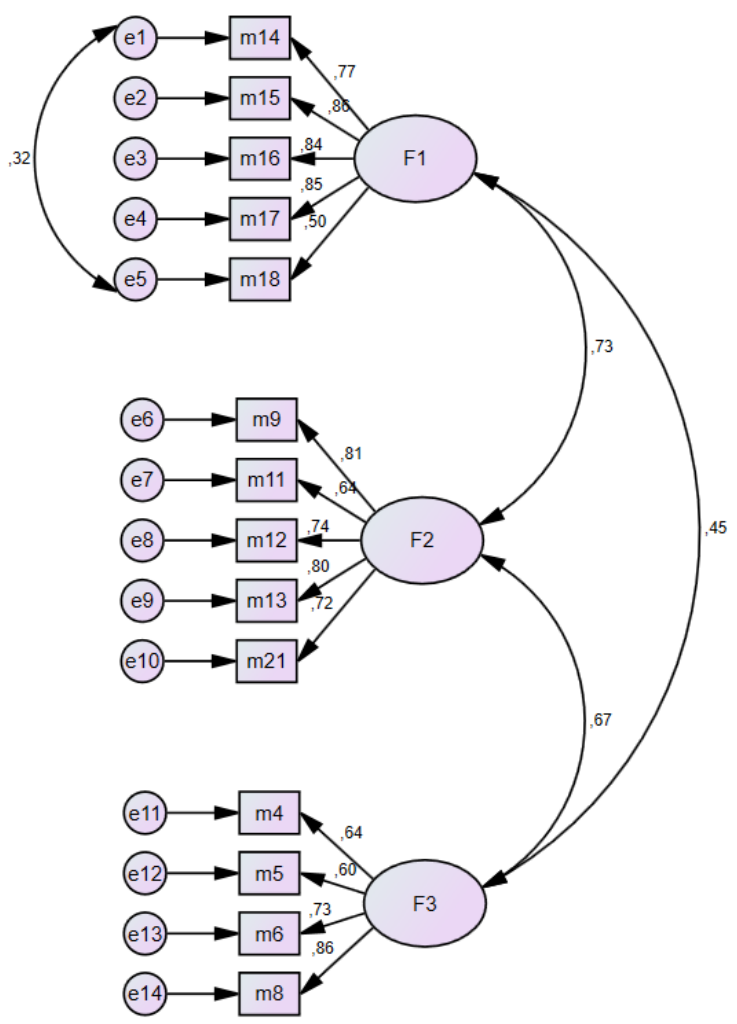

F1: Çevresel Zorlanma, F2: Farkındalık, F3: Duyuşsal Kaçınma

Şekil 2. Modifikasyon sonrası doğrulayıcı faktör analizine ilişkin path diyagramı 
Tablo 7. Ölçek alt boyutlarına ilişkin korelasyon AVE ve CR değerleri

\begin{tabular}{lcccccc}
\hline $\begin{array}{l}\text { Alt Boyutlar } \\
(\mathbf{n = 2 9 8 )}\end{array}$ & $\begin{array}{c}\text { Çevresel } \\
\text { Zorlanma }\end{array}$ & Farkındalık & $\begin{array}{c}\text { Duyuşsal } \\
\text { Kaçınma }\end{array}$ & AVE & CR \\
\hline Çevresel & $\mathrm{r}$ & 1 & $.647^{*}$ & $.360^{*}$ & 0.599 & 0.879 \\
Zorlanma & $\mathrm{p}$ & & .000 & .000 & & \\
\hline \multirow{2}{*}{ Farkındalık } & $\mathrm{r}$ & $.647^{*}$ & 1 & $.574^{*}$ & 0.557 & 0.862 \\
& $\mathrm{p}$ & .000 & & .000 & & \\
\hline Duyuşsal & $\mathrm{r}$ & $.360^{*}$ & $.574^{*}$ & 1 & 0.511 & 0.804 \\
Kaçınma & $\mathrm{p}$ & .000 & .000 & & & \\
\hline * p<0.01 & & & & & &
\end{tabular}

Tablo 7'de yapı geçerliğine kanıt sağlamak için literatür kapsamında (Devellis, 2016) alt boyutlar arası korelasyon değerlerinin hesaplanmasını önermektedir. Bu kapsamda yapılan analiz sonucunda ölçeğin alt boyutlar arasındaki korelasyon değerleri hesaplanmış, bütün alt boyutlar arasında pozitif ve anlamlı ilişkiler olduğu tespit edilmiştir $(\mathrm{p}<.01)$.

Başka bir ifade ile Kline (2015), ölçeği oluşturan örtük değişkenlerin farklı özellikleri ölçerken birbirileri ile de uyum içerisinde olması gerektiğini ifade etmektedir. Başka bir literatürde ise, örtük değişkenler arasındaki ilişki düzeylerinin .90 ve üzerinde olmaması önerilmektedir (Hair, Anderson, Tatham ve Black, 1998). Bu kapsamda ölçek alt boyutları arasındaki korelasyon değerinin 0.647 korelasyon katsayısını geçmediği tespit edilmiştir.

Bununla birlikte yakınsak geçerliğe kanıt sağlamak amacıyla faktör yük değerlerinden yola çıkarak AVE ve CR değerleri de hesaplanmıştır. Literatür kapsamında araştırmacılar AVE değerinin .50'den yüksek (Fornell ve Larcker, 1981), CR değerinin ise .70'in (Hair ve diğerleri, 1998) üzerinde bir değer olması gerektiğini belirtmektedir. Nitekim alt boyutlar için hesaplanan en düşük AVE değerinin 0.51, en düşük CR değerrinin ise, 0.80 olduğu tespit edilmiştir.

\section{Ölçeğin Güvenirliği}

“Engelli Bireylerde Spora Katılımın Önündeki Zorluklar Ölçeği”ne ilişkin Cronbach alpha $(\alpha)$ iç tutarlık katsayısı hesaplanmıştır. Bu aşamadan sonra ölçeği oluşturan maddelerin ayırt edicilik özelliğine ilişkin madde toplam test korelasyon değerleri de hesaplanmıştır. Bu iki analize ait değerler Tablo 8 ve 9'da sunulmuştur.

Tablo 8. Ölçek alt boyutlarına ilișkin iç tutarlılık katsayıları

\begin{tabular}{lc}
\hline Alt Boyutlar & Cronbach Alpha $(\boldsymbol{\alpha})$ \\
\hline Çevresel Zorlanma & .88 \\
Farkındalı & .86 \\
Duyuşsal Kaçınma & .79 \\
\hline Ölçek Toplam & .91 \\
\hline
\end{tabular}

Tablo 8'de görüldüğü gibi, alt boyutlar için elde edilen Cronbach Alpha değerleri, Çevresel Zorlanma için .88, Farkındalık için .86 ve Duyuşsal Kaçınma için .79 iken, ölçek için genel iç tutarlılık katsayısı ise . 91 olarak bulunmuştur. Tezbaşaran (1996), .70 ve üzeri değerlerin yeterli düzeyde olduğunu belirtmektedir. 
Başka bir literatürde ise, Nunnally ve Bernstein (1994), ölçeğin yüksek düzeyde güvenirliğe sahip olması için Cronbach alpha katsayısına ilişkin değerlerin .70 ilâ .90 aralığında olmasını önermektedir.

Tablo 9. Ölçek alt boyutlarına ilişkin madde toplam test korelasyon değerleri

\begin{tabular}{cccc}
\hline Maddeler & Ortalama & $\begin{array}{c}\text { Madde- Toplam Test } \\
\text { Korelasyonu }\end{array}$ & $\begin{array}{c}\text { Madde Silindiğinde } \\
\text { Alpha }\end{array}$ \\
\hline M4 & 2.29 & .463 & .904 \\
M5 & 2.12 & .416 & .906 \\
M6 & 2.36 & .572 & .900 \\
M8 & 2.77 & .560 & .893 \\
M9 & 1.99 & .733 & .900 \\
M11 & 2.81 & .575 & .900 \\
M12 & 2.74 & .691 & .895 \\
M13 & 3.03 & .752 & .893 \\
M14 & 3.16 & .687 & .895 \\
M15 & 3.16 & .649 & .897 \\
M16 & 2.95 & .673 & .896 \\
M17 & 2.90 & .700 & .895 \\
M18 & 3.02 & .410 & .906 \\
M21 & 2.96 & .606 & .899 \\
\hline
\end{tabular}

Tablo 9'da madde-toplam test korelasyon değerleri incelendiğinde, sonuçların .41 ile .70 arasında olduğu görülmektedir. Nunnally ve Bernstein (1994) madde-toplam test korelasyon değerinin .30 ve üzeri olan maddelerin ayırt edici özelliğinin iyi olduğunu belirtmektedir. Bununla birlikte ölçekten madde atılmasının Cronbach alpha $(\alpha)$ iç tutarlık katsayısını değiștimeyeceği de tespit edilmiștir.

\section{Tartışma ve Sonuç}

Literatür kapsamında engelli bireylerde spora katılım önündeki zorlanmaları belirlemeye yönelik ölçme aracına rastlanmamıştır. Bu boşluğun giderilmesi düşüncesinden hareketle, araştırma kapsamında engelli bireylerde spora katılım önündeki zorlanmaları geçerli ve güvenilir olarak ölçebilen bir ölçme aracının geliştirilmesi amaçlanmıştır. Bu kapsamda araştırmaya bedensel, işitme ve görme engelli bireylerden 139'u kadın, 159'u erkek olmak üzere toplam 298 kişi gönüllülük esası ile katılım sağlamıștır. Bu doğrultuda araștırma kapsamında yarı yapılandırılmış görüşme ve literatür taraması sonucu oluşturulan 32 ifadeden oluşan madde havuzu ilk olarak 7 uzman görüşüne sunularak kapsam geçerliği sağlanmıștır. Uzmanlardan gelen dönüşler doğrultusunda form 27 maddeye düşürülmüştür. $\mathrm{Bu}$ aşamadan sonra pilot çalışma sonrası oluşturulan 26 maddelik nihai form üzerinden geçerlik güvenirlik çalışmaları yapılmıştır.

“Engelli Bireylerde Spora Katılımın Önündeki Zorlanmalar Ölçeği”ne verilen yanıtların normal dağılıma uygunluğu için çarpıklık basıklık değerlerine bakılmış ve dağılımın normal olduğu soucuna ulaşılmıştır. Bu kapsamda ölçeğin yapı geçerliğinin test edilmesinde açımlayıcı faktör analizi kullanılmış ve bu analiz sonucunda elde edilen yapı 
sonrası doğrulayıcı faktör analizi kullanılmıştır. Açımlayıcı faktör analizi oluşan üç faktör yapısının varyansın \%66.785'ini açıkladığı tespit edilmiştir. Bu kapsamda aynı faktör altında toplanan toplanan maddelerin kapsamı ve kuramsal bilgiler dikkate alınarak bu boyutlar, "Çevresel Zorlanma", "Farkındalık" ve "Duyuşsal Kaçınma" olarak adlandırılmıştır.

Doğrulayıcı faktör analizi sonucunda elde edilen bulgular incelendiğinde ise, modifikasyon öncesi elde edilen değerlerin yeterli düzeyde olmadığı tespit edilmiştir. Bu kapsamda önerilen modifikasyonun yapılması sonucunda araştırma kapsamında modelin değerlendirilmesi için ele alınan uyum indeks değerlerinin ( $\mathrm{x}^{2} / \mathrm{df}$, RMSEA, SRMR, GFI, IFI) literatür bağlamında kabul edilebilir düzeyde uyum olduğunu göstermektedir (Byrne, 2010; Kline, 2015; Steiger 2000; Thompson, 2004). Doğrulayıcı faktör analizi sonrasında yakınsak geçerliğe kanıt sağlamak amacıyla açıklanan ortalama varyans (AVE) değerlerinin yanı sıra, yapı güvenirliği (CR) değerleri de hesaplanmıştır. Elde edilen bu değerlerin ölçeğin yapı geçerliğine kanıt oluşturduğu söylenebilir.

Ölçeğin yapı geçerliliğine kanıt sağlamak için diğer bir yöntem olan alt boyutlar arasındaki korelasyon değerleri de hesaplanmış ve bu analiz sonucunda tüm alt boyutlar arasındaki korelasyon değerlerinin pozitif ve anlamlı olduğu bulgusuna ulaşılmıştır. Ulaşılan bu sonuç kapsamında ölçeğin ayrışma geçerliğine (ıraksak geçerlik) sahip olduğu söylenebilir.

Bununla birlikte ölçeğin alt boyutlarına ilişkin iç tutarlık katsayıları Çevresel Zorlanma $(\alpha=88)$, Farkındalık ( $\alpha=86)$, Duyuşsal Kaçınma $(\alpha=79)$ olarak tespit edilirken ölçek için genel iç tutarlılık katsayısı ise $(\alpha=91)$ bulunmuştur. Elde edilen bu sonuçlar alt boyutlarda yer alan maddelerin birbirleriyle tutarlı olduğunu göstermektedir.

Bununla birlikte araştırma kapsamında ölçek maddelerinin Madde-toplam test korelasyon değerleri .41 ve .70 arasında değiştiği testpit edilmiştir. Elde edilen bu bulgu ölçeği oluşturan maddelerin iyi derecede ayırt edici özelliğe sahip olduğu ve bununla birlikte maddelerin ölçülmek istenen özelliği ölçtüğüne ilişkin kanıt oluşturduğu söylenebilir.

Tüm bu verilerden hareketle araştırma kapsamında geliştirilen ölçek veri toplama aracının 14 madde ve 3 alt boyutlu modeli ile engelli bireylerin spora katılımının önündeki zorlanmaları geçerli ve güvenilir bir şekilde ölçebilecek nitelik taşıdığı söylenebilir.

Yazışma Adresi (Corresponding Address):

Doktora Öğrencisi, Sevim Handan YILMAZ

Gazi Üniversitesi, Eğitim Bilimleri Enstitüsü, ANKARA

ORCID:0000-0002-1032-5082

E-posta: handanyilmazz@hotmail.com 


\section{Kaynaklar}

1. Altınkurt, N. (2008). Özel eğitim ve rehabilitasyon merkezlerinde yaşanılan sorunlar ve çözüm önerileri (Yüksek lisans tezi). Dokuz Eylül Üniversitesi, İzmir.

2. Byrne, B. M. (2010). Testing for the factorial validity of a theoretical construct. Structural equation modeling with AMOS: Basic concepts, applications and program. New York: Routledge Press.

3. Carpita, M. ve Maniser, M. (2011). On the imputation of missing data in surveys with likerttype scales. Journal of Classification, 28(1), 93-112.

4. Chinn, D. J., White, M., Howel, D., Harland, J. ve Drinkwater, C. K. (2006). Factors associated with non- participation in a physical activity promotion trial. Public Health, 120(4), 309-319.

5. Creswell, J. W. (2013). Research design: Qualitative, quantitative and mixed methods approach. California: Sage Publication.

6. Çevik, O. ve Kabasakal, K. (2013). Spor etkinliklerinin, engelli bireylerin toplumsal uyumuna ve sporla sosyalleșmelerine etkisinin incelenmesi. Uluslararası Sosyal ve Ekonomik Bilimler Dergisi, 3(2), 74-83.

7. Demir, G. ve İlhan, E. (2019). Spora katılım motivasyonu: Görme engelli sporcular üzerine bir araştırma. Gaziantep Üniversitesi Spor Bilimleri Dergisi, 4(1), 157-170.

8. Devellis, R. F. (2016). Scale development: Theory and applications. USA: Sage Publications.

9. Downey, R. G. ve King, C. (1998). Missing data in Likert ratings: A comparison of replacement methods. The Journal of General Psychology, 125(2),175-191.

10. Domjan, M. (2015). The principles of learning and behavior. USA: Wadsworth Publishing.

11. Ersoy, Ö. ve Avcı, N. (2000). Özel gereksinimli çocuklar ve eğitimleri "özel eğitim”. Ankara: YA-PA Yayıncilık.

12. Esatbeyoğlu, F., Balmumcu, O., Özdamar, E., Altıntaş, A. ve Aşçı, F. H. (2009, 20-22 Kasım). Spor yapan bedensel engellilerin güdüsel yönelimleri. Fiziksel Aktivite, Beslenme ve Sağlık Kongresi Bildiri Kitabı içinde (s.52). Başkent Üniversitesi, Ankara.

13. Esatbeyoğlu, F. ve Karahan, B. (2014). Engelli bireylerin fiziksel aktiviteye katılımlarının önündeki engeller. Spor Bilimleri Dergisi, 25(2), 43-55.

14. Fornell, C. ve Larcker, D. (1981). Gözlemlenemeyen değişkenler ve ölçüm hatası içeren yapısal eşitlik modellerinin değerlendirilmesi. Pazarlama Araştırmaları Dergisi, 18(1), 3950.

15. Gallahue, D. (1987). Develomental physical education for today's elementary school childeren. ABD: Jenson Books.

16. Güngör, B., N., Yılmaz, A. ve İlhan, E., L. (2019). Yaşam kalitesi bağlamında özel bir sporcunun kazanımları; ebeveyn görüşleri doğrultusunda bir durum çalışması. Ankara Üniversitesi Ĕ̆itim Bilimleri Fakültesi Özel Eğitim Dergisi, 20(3), 421-443.

17. Gravetter, F. J. ve Forzano, L.-A. B. (2012). Research methods for the behavioral sciences. Massachusetts: Cengage Learning.

18. Hair, J. F., Anderson, R. E., Tatham, R. L. ve Black, W. C. (1998). Multivariate data analysis. New Jersey: Prentice Hall Collage.

19. İlhan, E. L. (2008). Zihinsel engelli çocuklar için beden eğitimi ve sporun genel gelişim süreçleri açısından önemi. Çağdaş Eğitim Dergisi, 33(350), 17-24.

20. İlhan, E. ve Esentürk, 0. (2014). Zihinsel engelli bireylerde sporun etkilerine yönelik farkındalık ölçeği (ZEBSEYFÖ) geliştirme çalışması. CBÜ Beden Eğitimi ve Spor Bilimleri Dergisi, 9(1), 19-36. 
21. İlhan, E., Orhan, E. ve Yarımkaya, E. (2018). İki farklı özel eğitim ve rehabilitasyon merkezinin aktivite profilinin incelenmesi. Spor ve Performans Araştırmaları Dergisi, 9(2), 110-126.

22. İnal, S., Akdur, H., Donuk, B., Güngördü, O., Kaya, B., Kesler, A. ve Kırandı, Ö. (2007, Mayıs). Zihinsel engelli çocuklara spor eğitimi ile bedensel sağlĭı̆ kazandırılması. Engellilerde Sanat ve Spor Sempozyumu (ss. 225-240). Hacettepe Üniversitesi, Ankara.

23. Jaarsma, A., Dijkstra, P. U., Geertzen, J. H. B. ve Dekker, R. (2014). Barriers to and facilitators of sports participation for people with physical disabilities: A systematic review. Scandinavian Journal of Medicine and Science in Sports, 24(6), 871-881.

24. Kabasakal, K. (2007). Zihinsel engellilik, zihinsel, ruhsal, duygusal engellilik. İstanbul: Ünimat Ofset Matbaası.

25. Kalyon, T. A. (1994). Spor hekimliği. Ankara: Gata Basımevi.

26. Kirchner, C. E., Gerber, E. G. ve Smith, B. C. (2008). Designed to deter: community barriers to physical activity for people with visual or motor impairments. American Journal for Preventive Medicine, 34(4), 349- 352.

27. Kline, R. B. (2015). Principles and practice of structural equation modeling. New York: Guilford Press.

28. Konar, N. ve Yıldıran, İ. (2012). Engelliler için beden eğitimi ve spor öğretmenliği: gereksinim ve bir program modeli. Selçuk Üniversitesi Beden Eğitimi ve Spor Bilim Dergisi, 14(2), 208-216.

29. Nalbant, S. ve Izgar, N. (2018). Özel eğitim ve rehabilitasyon merkezi kurumlarının beden eğitimi öğretmeni istihdamına bakış açısı. Ulusal Spor Bilimleri Dergisi, 2(1), 68-83.

30. Nunnally, J. C. ve Bernstein, I. (1994). Psychometric theory. New York: McGraw-Hill.

31. Savucu, Y. ve Biçer S. Y. (2009). Zihinsel engellilerde fiziksel etkinliklerin önemi. Türkiye Klinikleri Journal of Sport Science, 1(2), 117-122.

32. Savucu, Y., Sirmen. B., İnal, S., Karahan, İ. ve Erdemir, İ. (2006). Zihinsel engelli bireylerde basketbol antrenmanının fiziksel uygunluk üzerine etkilerinin belirlenmesi. Fırat Üniversitesi Sağllk Bilimleri Dergisi, 20(2), 105-113.

33. Steiger, J. H. (2000). Point estimation, hypothesis testing, and interval estimation using the RMSEA: Some comments and a reply to Hayduk and Glaser. Structural Equation Modeling, 7(2), 149-62.

34. Tabachnick, B. G. ve Fidell, L. S. (2013). Using multivariate statistics. California: Pearson Publish.

35. Tekkurşun, D. G., İlhan, E. L., Esentürk, O. K. ve Kan, A. (2018). Engelli bireylerde spora katılım motivasyon ölçeği (ESKMÖ): geçerlik ve güvenirlik çalışması. Spormetre Beden Eğitimi ve Spor Bilimleri Dergisi, 16(1), 95-106.

36. Tenenbaum, G. ve Eklund, R. C. (2007). Exercise adherence. Handbook of sport psychology. New Jersey: John Wiley ve Sons Inc.

37. Tezbaşaran, A. (1996). Likert tipi ölçek hazırlama kılavuzu. Ankara: Türk Psikologlar Derneği Yayınları.

38. Thompson, B. (2004). Exploratory and confirmatory factor analysis: Understanding concepts and applications. Washington: American Psychological Association.

39. TDK (2019). Güncel sözlük. https://sozluk.gov.tr/ adresinden 20.02.2021 tarihinde erişilmiştir.

40. WHO (2001). International classification of functioning, disability and health. WHO Library Cataloguing-in-Publication Data.

41. Watson, D. (2002). Positive affectivity: The disposition to experience pleasurable emotional states, In C.R. Synder \& Shane J. Lopez (Eds), Handbok of Positive Psychology. Newyork: Oxford University Press. 
Ek 1: Engelli Bireylerde Spora Katılımın Önündeki Zorlanmalar Ölçeği

\begin{tabular}{|c|c|c|c|c|c|}
\hline & 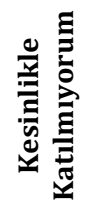 & : & 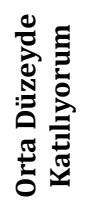 & $\underset{\Xi}{\Xi}$ & 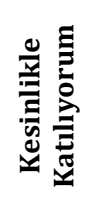 \\
\hline 1. Spor için ayıracak zamanım yok. & 1 & 2 & 3 & 4 & 5 \\
\hline $\begin{array}{l}\text { 2. Sporun engel düzeyimi arttırabileceğine } \\
\text { inanıyorum. }\end{array}$ & 1 & 2 & 3 & 4 & 5 \\
\hline 3. $\quad$ Spor yapmaya ilgi duymuyorum. & 1 & 2 & 3 & 4 & 5 \\
\hline 4. Spora yönelik bir yeteneğim olmadığına inanıyorum. & 1 & 2 & 3 & 4 & 5 \\
\hline $\begin{array}{l}\text { 5. Bir spora başlasam devam edemeyeceğimi } \\
\text { düşünüyorum. }\end{array}$ & 1 & 2 & 3 & 4 & 5 \\
\hline $\begin{array}{l}\text { 6. } \begin{array}{l}\text { Antrenörlerin engelliler konusunda gerekli } \\
\text { formasyona sahip olmadı̆ı̆ı düșünüyorum. }\end{array} \\
\end{array}$ & 1 & 2 & 3 & 4 & 5 \\
\hline $\begin{array}{l}\text { 7. Spor ortamlarında sosyal olarak dışlanacağımı } \\
\text { düşünüyorum. }\end{array}$ & 1 & 2 & 3 & 4 & 5 \\
\hline $\begin{array}{l}\text { 8. Spor yapmak için bana eşlik edecek / destek olacak } \\
\text { kimse yok. }\end{array}$ & 1 & 2 & 3 & 4 & 5 \\
\hline 9. $\quad$ Spora katılım için ne yapacağımı bilmiyorum. & 1 & 2 & 3 & 4 & 5 \\
\hline $\begin{array}{l}\text { 10. Spor tesisleri iç donanımlarının (erişim, duş, wc vb.) } \\
\text { bana göre olmadığını düşünüyorum. }\end{array}$ & 1 & 2 & 3 & 4 & 5 \\
\hline 11. Spor ortamları hijyen açısından uygun değildir. & 1 & 2 & 3 & 4 & 5 \\
\hline $\begin{array}{l}\text { 12. Spor ortamları çevresel düzenlemeler ya da } \\
\text { ergonomi yönünden güvenli değildir. }\end{array}$ & 1 & 2 & 3 & 4 & 5 \\
\hline $\begin{array}{l}\text { 13. Spor tesislerine ulaşımda zorluk yaşayacağımı } \\
\text { düşünüyorum. }\end{array}$ & 1 & 2 & 3 & 4 & 5 \\
\hline 14. Gelir düzeyim düşük olduğu için spor yapamıyorum. & 1 & 2 & 3 & 4 & 5 \\
\hline
\end{tabular}

\section{Alt Boyutlar}

- Duyuşsal Kaçınma: Madde No: 1, 2, 3, 4

- Farkındalık: Madde No: 5,6, 7, 8, 9

- Çevresel Zorlanma: Madde No: 10, 11, 12, 13, 14 